\title{
The Use of a Constructivist Blended Approach to Teaching Geography in a Secondary School
}

\author{
Deidra Margaret Richards ${ }^{1}$, Roland Birbal $^{2} \&$ Mala Ramdass ${ }^{2}$ \\ ${ }^{1}$ The University of the West Indies, Trinidad and Tobago \\ ${ }^{2}$ Corinth Campus, University of Trinidad and Tobago, Trinidad and Tobago \\ Correspondence: Deidra Margaret Richards, The University of the West Indies, Trinidad and Tobago.
}

Received: November 6, 2020

Accepted: December 4, 2020

Online Published: December 18, 2020

doi:10.20849/aes.v5i2.819

URL: https://doi.org/10.20849/aes.v5i2.819

\begin{abstract}
This action research study used qualitative and quantitative methods to investigate students' performance in assessments and their perceptions and experiences with the use of a constructivist blended approach to teach secondary school geography. The constructivist blended model which used the 5-E strategy (Engage, Explore, Explain, Elaborate and Evaluate) informed teaching and assessment. Methods of data collection were test scores, an open-ended questionnaire, and a focus group interview.

Findings suggest that although students' performance in the assessment and their perceptions and experiences of the constructivist blended classroom strategy were generally positive, several students felt challenged by its use. Students participated minimally in online discussions, and few read online resources. Furthermore, classroom discussions were still mostly teacher directed as many students experienced a high level of fear and anxiety with in-class presentations. A reliance on educators as the main source of knowledge persisted, with reluctance by some to assume an independent role in their learning. We conclude that although students generally approved of the strategy, and performed better in the assessments, their experiences of schooling in an authoritarian, post-colonial education system challenged its effective use.
\end{abstract}

Keywords: action research, blended learning, constructivism, 5-E strategy, Caribbean

\section{Introduction}

Action research is a tool that can be used to help educators test a new instructional strategy, assess a new curriculum program, or evaluate an existing pedagogical approach to improve teaching practices (Sagor, 2004). Participating in action research has been found to enhance classroom practices and improve teacher self-reflection and overall learning (Sax \& Fisher, 2001).

This study uses action research to implement a constructivist blended approach to deliver the Geography syllabus to two groups of form 3 students. As education systems seek to develop the $21^{\text {st }}$ century learner, Geography remains a relevant discipline for the engagement of students at the secondary school level. The interdisciplinary nature of Geography and its emphasis on global learning allows students to be civic minded and environmentally-sensitive (Collymore, 2013).The latest Geography syllabus for the Caribbean Secondary Education Certificate (CSEC) of the Caribbean Examinations Council (CXC) that was implemented for the 2017 examination and beyond stated that there was the need to develop learners who possess higher order thinking skills with the ability to solve everyday problems unique to our Caribbean situation (Caribbean Examinations Council, 2015). The teaching of geography using digital tools has much to offer a face-to-face classroom, but those tools must be effectively implemented according to relevant education theories. Constructivist learning theory can provide a framework for the use of digital tools to integrate online and face-to-face learning experiences to create a constructivist blended learning environment to enhance student learning.

\subsection{The Problem}

The performance of students in Geography at all levels of the school under study has been much lower when compared to their performance in other subject areas in the curriculum. In this school, the number of students receiving grade I in Mathematics and English were above $90 \%$ for the CSEC examinations for the period 2016 to 2018. In contrast, the number of students receiving grade I in CSEC Geography for the same period were 55\% in $2016,52 \%$ in 2017 and $61 \%$ in 2018. This disparity in students' performance may be due to the way in which 
the Geography curriculum is delivered. Studies have revealed that the way the Geography syllabus is delivered throughout the school system does not encourage critical thinking or independent learning (Collymore, 2013; Kubiatko, Janko, \& Mrazkova, 2012). Dictation of notes, rote learning and memorization is encouraged in the traditional method of teaching where the teacher is the centre of the classroom and students passively absorb all the content that the teacher is passing on (Korkmaz \& Karakus, 2009; Kubiatko et al., 2012; Ozdemir, 2012).

The Caribbean Secondary Examination (CSEC) Geography syllabus is a very content-heavy syllabus. In an effort to complete it, many Geography teachers in the Caribbean deliver the syllabus by implementing a more didactic, expository type of teaching method to cope with the wide scope and great depth of the syllabus (Al-Nofli, 2010; Collymore, 2013; Kubiatko et al., 2012). However, this approach has not been producing the best results. (Caribbean Examinations Council, 2017).

Though studies exist on the problems associated with teaching Geography in the traditional method, there are few studies about the blended learning approach in the teaching of Geography (Abidoye, 2015; Viz \& Kaur, 2017). Therefore, this study attempts to use a constructivist blended learning approach as an intervention to improve student learning/understanding of geography concepts.

\subsection{School Context}

The 55 students who participated in this study attend a denominational school in the Port of Spain and Environs education district of Trinidad. This school adopted a 7-year education program. Boys attend the school at the final two years, but the intake for the first 5 years consists of only girls. All students that took part in the study were form 3 students between the ages of 13 and 16. At this level the students are required to do thirteen subjects: English Language and Literature, Spanish, French, Chemistry, Physics and Biology, History and Geography, Information Technology, Art, Music and Mathematics. Most of these students are high-achievers who scored in the top $97 \%$ in the secondary school assessment (SEA) national examinations three years prior to the study, to gain entry into this school. The students are from a variety of socio-economic backgrounds, ethnicities and religions.

\subsection{Area of Focus Statement}

The purpose of this study was to provide insights into students' performance in assessments and their perspectives and experiences of the constructivist blended classroom strategy for the delivery of the Geography curriculum in one secondary school in the Port of Spain and Environs education district of Trinidad. The researchers were also interested in uncovering some of the challenges that students faced with the use of this instructional strategy. This area of focus statement satisfies the central tenets of action research in that "it involves teaching and learning, is something that is within my locus of control, is something I feel passionate about, and is something I would like to change or improve" (Mills, 2000, p. 27).

\section{Research Questions}

The main research question that the investigation addressed was:

What are secondary school students' perceptions and experiences with the use of the constructivist blended learning strategy in the delivery of the geography curriculum?

The sub-questions were:

1. What are the students' perceptions of the constructivist blended learning strategy for the delivery of the Geography curriculum? (Do students perceive that the constructivist blended learning strategy enhances their learning?)

2. What attitudes do students exhibit towards the use of the constructivist blended learning strategy for the teaching of geography?

3. What challenges do students experience with the use of the constructivist blended learning classroom strategy?

\section{Review of Related Literature}

\subsection{Constructivist Blended Learning Defined}

Constructivist theories of learning describe learning as a process whereby the learner takes in information and inserts it into existing schema. Each learner constructs meaning differently based upon their own experiences. In other words, there is a disconnect between knowledge that is taught, and knowledge that is learned, because the learner will re-interpret what is being taught, and construct his or her own meaning from that knowledge. It has been argued that constructivist, inquiry-based methods of teaching are best at promoting the acquisition and 
demonstration of knowledge at higher cognitive levels while increasing student enjoyment of learning (Thaiposri \& Wannapiroon, 2015).

Blended learning, also referred to as hybrid learning or mixed learning (Hrastinski, 2019), allows students to manipulate multimedia and content at their own pace asynchronously, and students are in control of the time and place of learning (Gharacheh et al., 2016). According to Bryan and Volchenkova (2016), there is a range of definitions of blended learning. Lalima and Dangwal (2017) argued that "Blended learning incorporates direct instruction, indirect instruction, collaborative teaching, individualized computer assisted learning" (p. 131). Blended learning was also described as an education program where students learn partly through the online delivery of content and instruction, where there is student control over time, place and pace of learning and partly in a central supervised setting (such as a school or community centre) away from home (Bailey, Ellis, Schneider \& Ark 2013). Others argued that blended learning is not only about the combining of teaching strategies, but it includes blending media formats as well (Hrastinski, 2019). Constructivism supports the blended learning environment, as it provides students with the opportunity to engage with lesson materials outside of class and to construct their own knowledge while working with others.

In this study the understanding of the constructivist blended learning strategy gives students opportunities for "constructing" their own knowledge and skills through experiential and interactive learning activities using the 5Es (the five phases of Engagement, Exploration, Explanation, Elaboration and Evaluation). It includes not only the combination of delivery methods but also the increased use of technological aids (e.g. presentation software, videos and other applications) both in the classroom setting and online - within the classroom and a remote location.

The common factor in all schools which used blended learning was that many different web applications, instructional software and web enabled communications had to be adopted. This included a number of platforms such as Learning Management Systems (LMS) where teachers had the flexibility to provide their own content (Dikmenli \& Unaldi, 2013); social learning platforms where teachers could collaborate with colleagues and students and platforms that could also store content and keep track of student performance on assessments. Most of the LMSs that are used today include discussion boards, online assessment and data platforms which give immediate feedback to students and allows the teacher to focus on the specific objective(s) that are giving students difficulties (Bailey et al., 2013). Constructivist learning theory provides a framework for integrating online and face-to-face learning experiences to create a constructivist blended learning environment for effective learner development.

\subsection{Students' Perceptions of Blended Learning}

Previous studies have shown that students' perceptions of the blending of face-to-face classes with online instruction are generally positive (Hesse, 2017). The results obtained from a study of secondary school Biology students in Turkey found that students seemed to favour the online component of blended learning more than physical face-to-face sessions. While students felt that the face-to-face class time was essential for things like clarification of problems and instant feedback by teachers, the majority of the students saw the online component of the blended learning method as very enjoyable and welcomed the ability to direct their own learning at their own pace, and the visual detail to aid in understanding lessons (through pictures, videos and animation) that were offered by the online environment (Yapici \& Akbayin, 2012). They however, cited technological challenges in using the blended learning environment which included unreliable internet connections and problems opening videos and websites.

Similarly, Martinsen, Jackson and Whitehouse (2015), in their study of a secondary school in Australia also found that students enjoyed the flexibility of access to content at various times and places and the ability to work independently by either preparing for class beforehand or reviewing what was done repeatedly. However, some believed that the face-to-face times with the teacher were essential for feedback. The study also found that only a few students felt more comfortable with a teacher directed classroom scenario than learning online. One of the reasons given for this was that they were not used to learning independently, some preferred "the teacher telling them what to do" (Martinsen, Jackson, \& Whitehouse, 2015, p. 105).

A longitudinal study, also done in Australia, on using blended learning to teach Mathematics in the secondary school produced even more favourable results for the online learning component (White, Barnes, \& Lawson, 2013). This study showed that students believed that they learnt better with the online component, rather than if there was only the face-to-face teaching. They too lauded the accessibility benefit of blended learning. Their positive perception was also because it allowed them a certain level of independent learning. They also believed 
that blended learning created an environment that led to them understanding the material better since they had access to many resources including interactive learning objects such as tutorials.

\subsection{Theoretical Framework}

This research was informed by the principles of constructivism as proposed by Gharacheh, Esmaeili, Farajollahi and Jamalzadeh (2016) and Olusegun (2015). They identified two types of constructivism - individual constructivism and social constructivism - both of which can be achieved by blending virtual environments with the traditional classroom. Both types of constructivism used in the blended learning approach ultimately leads to the formation of several higher-level thinking skills including critical thinking, problem solving and creativity (Al-Huneidi \& Schreurs, 2012; Gharacheh et al., 2016).

The basic premise of individual constructivism is that knowledge does not exist outside of oneself but must be 'constructed' based on one's experiences and interactions with the world (Schunk, 2012). Consequently, it is essential that teachers create situations that allow learners to interact with their environment through manipulation of materials $(\mathrm{Li}, 2017)$. It is an active process. After interacting with their environment students learn by fitting in new information into what they already know (assimilation) or by interacting with material that forces them to reconstruct old ways of thinking (accommodation) (Olusegun, 2015).

In social constructivism, learning takes place due to interactions between persons in their social environment. This would allow them to "reorganise" the cognitive structures already attained (Schunk, 2012, p. 242). In this way, they are encouraged to analyse their own thinking, evaluate it and that of others. As students interact with each other, their facilitators, and the content, learning takes place (Li, 2017). This interaction can be synchronous or asynchronous. Activities within the blended learning environment that promote social constructivism include discussion boards, collaborative project work, group presentations and online video conferencing in addition to face-to-face collaborations and discussions. When learning involves different activities such as "first hand experiences, secondary resources, interactive materials, independent search, interaction and discussion with others", all those differing views on a subject lends itself to the development of critical thinking skills (Gharacheh et al., 2016, p. 1140).Therefore, the nature of the blended learning process effortlessly leads to the application of constructivist methods of learning ( $\mathrm{Li}, 2017)$.

There are many models based on the principles of constructivism that can be applied to the blended learning environment. These are called inquiry-based learning models. Inquiry-based learning is a procedure whereby students are the centre of their learning. They are involved in framing questions and conducting research to build their own understanding of concepts and bring new meaning to existing knowledge (Vaughan, 2015).

The model that will be employed in this study is the ' 5 -E' model of inquiry. According to Thaiposri and Wannapiroon (2015), in this model the 5Es stand for the five phases of Engagement, Exploration, Explanation, Elaboration and Evaluation. In the engagement phase, the teacher engages the student's interest in a new concept through a short activity. Exploration involves the use of different activities to generate innovative ideas, explore questions, research, or conduct an investigation. In the Explanation phase, the student is provided with the opportunity to demonstrate their conceptual understanding of what they explored. The Elaboration phase allows the student to apply this understanding to broader activities and in the Evaluation phase the teacher assesses the students' progress towards the achievement of the educational objectives. In this study, videos, interactive games and group engagement in online and class activities were all used to create a constructivist learning environment.

\section{Methodology}

This action research study used both qualitative and quantitative methods to gather data from two groups of Form 3 students on their perceptions and experiences with the use of a constructivist blended teaching approach in the delivery of the geography curriculum. Action research involves teacher researchers in a four-step cyclical process that includes the following: identifying an area of focus, data collection, data analysis and interpretation, and action planning. It is through the categories of this design that the following will describe the process in which the design for this action research project was created.

\subsection{Planning}

Planning involves "Identifying and limiting the topic, gathering information, reviewing the related literature and developing a research plan" (Mertler, 2014, p. 36). The planning stage of the study was conducted from April $30^{\text {th }}$ to May $1^{\text {st }} 2018$. Several factors had to be considered to develop a plan to answer the research questions for this paper. These included the topic to be taught, the time frame to conduct the study, the learning management system (LMS) to be used and the training of the students to be able to use the LMS.

The decision to use the CANVAS Instructure LMS was made because of the researcher's familiarity with the 
software. After deciding on the LMS, students were trained to use the LMS. The topic of tourism was selected as this is the topic that is usually delivered during the term that the study was conducted according to the Geography curriculum.

\subsection{Acting}

This phase of the action research took place during a four-week period from $2^{\text {nd }}$ May to May 25th, 2018 during the $3^{\text {rd }}$ term of the academic year for secondary schools in the country. Data were collected prior to, during, and after the implementation of the constructivist blended learning approach. The form 3 students were taught a unit on Tourism from their Geography syllabus using a blended learning teaching approach. This approach included a combination of face-to-face instruction, a mixture of online activities, self-directed activities, and cooperative group work which were carefully designed and research driven.

For this research, students were taught using the principles of inquiry-based learning and supported by a blended learning strategy which we have termed a constructivist blended learning strategy. This strategy allowed the teacher and students to make full use of the features in the LMS such as discussion boards and emails.

The two form 3 classes/groups were taught the same content on the topic of 'tourism'. Tourism is one of the topics usually taught at this level in the geography syllabus for the third term (Mid April to Mid July) in the school calendar. The topic objectives were arranged into four modules which were studied on a weekly basis for four weeks.

The classes were taught by the same teacher, three times a week for forty minutes each. Prior to the study, all students were questioned about their ability to access the internet and devices at home and they all positively responded that they had access to both.

The Canvas Instructure LMS has an online version that is free for individual teachers to use. One month prior to the study, the subject portal was designed by the researcher for use by the students. Students had access to the portal on any of their devices, whether they were used at school, home or anywhere else, once an internet connection was available.

The '5-E' instructional model was used since this is a popular model used in the sciences and geography to ensure that a learning experience adheres to the principles of constructivism. The design of activities for each module was guided by this model. Each module contained activities to Engage students; allowed them to Explore a topic through their own research; gave them opportunities to Explain what they learnt and Elaborate on it by applying it to a 'real world' situation. The process ended with an Evaluation of the main concepts from that week's activities.

Seventy five percent $(75 \%)$ of the topic content was delivered solely online, given in the form of text, video, discussions and multimedia aids. The remaining $25 \%$ of the content was taught in the face-to-face classroom. The online component consisted of many activities which culminated into two main projects - namely the creation of a tourism brochure for a country of their choice and a presentation of tourist attractions in their country and another country washed by the Caribbean Sea. The classroom time was used to discuss, elaborate on and demonstrate concepts they learnt online, finish projects and teach new content, pertinent to both projects. The classroom content was covered in the school's multimedia room which is equipped with desktop computers and laptops for students to work in pairs, along with an over-head projector and a computer for the teacher's use.

Problem-solving tasks and the production of a brochure were done online and collaboratively using applications such as Lucidpress, Google Docs, Google Slides and Google Maps. The LMS Canvas Instructure was used as the platform through which assignments and quizzes were given and online discussions carried out, as indicated previously.

\subsection{Data Collection}

Data were collected through test scores, an open-ended questionnaire and a focus group interview. Test scores of two Form 3 classes which were taught in the traditional teacher directed approach the previous year were compared with the scores of the two form 3 classes under study who were taught using a blended learning strategy. The means and standard deviation of marks were calculated for each strategy to find out if there were any changes in performance.

At the end of the four-week teaching period, students' performance in the examination of the topic of Tourism was also collected. Students were also asked to complete an open-ended questionnaire to elicit their perceptions of the blended learning process. It consisted of 5 open-ended questions and one closed question. Three days later, twelve students were selected from the combined classes to form one focus groups. 
This focus-group interview was conducted by the researcher. The questions from the questionnaire were repeated for the focus group session. This was done to allow students the ability to state their opinions more fully and allow them to add to what others may have said as well.

\subsection{Sample Selection}

The form 3 secondary school students were all girls whose ages ranged from 13 to 16 . Fifty-five (55) out of a total of sixty-six (66) students from the two different classes participated in this study. The eleven students who did not return their parental permission slips were not included in the data collection. These classes were chosen using convenience sampling as they both had to be taught the same topics and there was very little time for additional teaching in the school term. The twelve participants in the focus group interview were chosen using purposive sampling. The students' final grades in Geography for the previous academic term were obtained. Four students who were high-performing, four who were low-performing and four-middle performing students were chosen according to purposive sampling.

\section{Data Analysis and Interpretation}

The analysis of the questionnaire data was done following the recommendations of Creswell (2012). The data from the questionnaires were placed into folders according to the two groups and numbered. The responses for the first question of the questionnaire were read for each group to obtain a general understanding of the data.

The responses were then analysed. The researcher grouped all phrases according to categories or themes. A record was then made of the themes that emerged along with corresponding questionnaire numbers for identification. This was done for each question separately. Each theme was noted and the number of students from both groups who responded according to that particular theme was tallied.

The focus group interview was then conducted, and the responses were transcribed to a Microsoft Word document. The responses were read once, to obtain a general idea of the data, and a second time to see if any other themes besides those in the questionnaire emerged.

5.1 Responses to Sub-Question 1: What Are the Students' Perceptions of the Constructivist Blended Learning Strategy for the Delivery of the Geography Curriculum? (Do Students Perceive That the Constructivist Blended Learning Strategy Enhances Their Learning?)

The two main themes that emerged from the analysis of the data for this sub-question was that blended learning created a better classroom atmosphere, but it was stressful and difficult.

\subsubsection{Better Classroom Atmosphere}

Students perceived that blended learning led to a better classroom atmosphere. This perception was attributed to a few factors.

\subsubsection{Classes Not Boring/More Fun}

When students were asked about their perception of blended learning in the questionnaire, more than half (35 students out of fifty-five students) described the use of blended learning as fun or that it made the classroom 'not boring'. About one third (4 out of 12) of the students in the focus group interview also echoed a similar view. When asked if the blended learning environment made them enjoy the topic of tourism more than other topics taught in geography more than half ( 31 out of 55) of the students responded positively. Some of the responses were as follows:

"Personally, I thought it was helpful to have classes online and in the classroom. It was a bit of fun and it helped me learn about the useful learning tactics that can help me in the future."

“...Because for me in a classroom its very boring, usually you just take notes and but this time it was different because we were all in groups and it was actually more fun to learn...."

"In my opinion, it was a really good learning experience since we got the chance to learn from various sources instead of only one...."

"I enjoyed the online aspect and doing presentations because I feel like I knew a lot more without studying than if we just write notes and learn them...."

This result is similar to the study conducted by White, Barnes and Lawson (2013) where students admitted to enjoying their interactions with learning resources during blended learning. 


\subsubsection{Allowed for Increased Interactivity}

The majority ( 45 out of 55) of the students commented about the increased interactivity that the blended learning environment provided compared to the traditional classroom.

"In my opinion, I think that the use of both an online environment and the classroom made tourism more informative and interactive as we could have used the internet to search up more information on that topic and also learn more about tourism from other people's notes."

"...I enjoyed it because it was interactive instead of the everyday lectures and writing in books."

\subsubsection{Facilitated a Better Understanding of the Topic}

About three quarter (41 out of 55) of the students claimed to understand the topic better because of blended learning. Some of the comments from students were as follows:

"Yes, because it was easier to learn some things through playing a game or seeing a picture of something so as to better understand it."

“...through various online activities like videos, interesting assignments and mini quizzes etc. it makes the learning experience more fun and diverse. Also, I found myself not even needing to study intensely for this topic because I understood it completely and somehow, it's like all definitions are imprinted in my head!"

Students' understanding of the geography concepts was reflected in the grades obtained in the two quizzes that examined students' understanding of the tourism modules 1 to 3 . Module 4 was examined using the students' responses in the online discussion.

Participants in Group A and Group B who were taught with the constructivist blended approach obtained higher scores Group A $(M=93, S D=9.70)$ and Group B $(M=93, S D=10.4)$ when compared to the scores obtained by the two groups of students who were taught using a teacher-directed approach $(\mathrm{M}=79.4, \mathrm{SD}=11.97)$ and $(\mathrm{M}=$ $78.2, \mathrm{SD}=12.16$ ) respectively (Table 2 ). There was a greater variability in the scores of students who were taught in the traditional format.

Table 2. Minimum, maximum, mean scores and standard deviation of test scores

\begin{tabular}{lllll}
\hline GROUP & $\begin{array}{l}\text { Highest } \\
\text { Percentage }\end{array}$ & $\begin{array}{l}\text { Lowest } \\
\text { Percentage }\end{array}$ & $\begin{array}{l}\text { Mean } \\
\text { Percentage }\end{array}$ & $\begin{array}{l}\text { Standard } \\
\text { Deviation }\end{array}$ \\
\hline Group A (BL) & 100 & 73 & 93 & 9.70 \\
\hline Group B (BL) & 100 & 67 & 93 & 10.49 \\
\hline $\begin{array}{l}\text { Previous } \\
\text { Groups A (Traditional Approach) }\end{array}$ & 100 & 45 & 79.4 & 11.97 \\
\hline $\begin{array}{l}\text { Previous groups B } \\
\text { (Traditional Approach) }\end{array}$ & 95 & 40 & 78.28 & 12.16 \\
\hline
\end{tabular}

\subsubsection{Innovative and Effective Use of Technology}

Students perceived that blended learning was an innovative and effective method. About one fifth (11 out of 55 students) claimed that its effectiveness was due to the use of technology, especially since it allowed learning to be very accessible regardless of time or place. Comments included:

"..And when we have it [classes] online, we can access it anywhere and that was easy for us because in a class you probably won't remember what a teacher say but we can go online and see what the teacher actually put up for us..."

"It introduced me to a new way of learning things. With the use of both technology and in class learning, I personally love technology and it made me more interested in learning the topic."

This belief is akin to the students in the study conducted by Martinsen, Jackson and Whitehouse (2015), where students commended the blended learning process for the increased accessibility it offered.

Students were also glad that the class was moving in the same direction as the rest of the world and using technology more in education. 
"The use of both is beneficial as society is becoming more technologically advanced and we really have to be ready...."

"I think that it is a good idea because this generation is more used to online environments so that it is easier for them to relate to studying through the use of an online environment...."

\subsubsection{Stressful and Difficult}

Despite the positive views about the blended learning process, several students (12 out of 55) described it as being stressful or difficult. The factors responsible for this opinion were varied.

\subsubsection{Not Enough 'Note-Taking'}

The issue of note-taking was not only the reason for a positive perception of blended learning but also a negative perception of the blended learning strategy. Of the negative comments made by students, less than $20 \%$ of the students (10 out of 55) claimed that they did not like using blended learning because there was less notes being given out by the teacher. When asked their perception about the process, one student in the focus group admitted:

".....Definitely less spoon feeding through notes, you [we] had to fight it for ourselves..."

In addition, a small number of students (6 out of 55) stated that there was a lack of understanding of the topic because it was taught through blended learning. Most of these students (4 out of 6) linked it to a lack of notes.

\subsubsection{Too Much Independent Learning Expected}

In the questionnaire, one of the main reasons identified for blended learning being stressful was because of the research that they had to do on their own:

"It was stressful as I was not used to doing that amount of research."

"Research takes a long time and with the number of other subjects that I have to do, it can be a bit stressful.

In the focus group, at least two students also identified this as the reason for a stressful experience. In this group a high performing student admitted that she thought the tourism game was fun at first but then stressful when she realised that she had to apply critical thinking in order to figure out the main theme of the game. She compared it to when the teacher usually tells them exactly what needs to be learnt.

“...normally in class Miss would have a slide and bullet points, attractions, amenities whatever, but in the game it was ......stressful because you had to get the points, it wasn't straightforward you had to go behind it in the game and so ok, what is the point of having this part in the game to get the answer..."

It was also observed that at the end of the first week of teaching, when the mapping activities that would take place the following week were explained to students, one of them asked if it were possible that they could sit and take notes in class instead. They wanted the teacher to lecture to them instead of using guided discovery activities through mapping to understand concepts. Some students in the study by Martinsen, Jackson and Whitehouse (2015) also felt that they were not prepared for independent learning and preferred it when the teacher dictated notes to them.

\subsubsection{Lack of Access to Reliable Technology}

Of the 10 (out of 55) students that gave technology as the reason for their negative or mixed views of blended learning, 5 out of that 10 claimed that it was due to unreliable internet or computer issues at home.

\subsubsection{Malfunctioning Websites}

About one third (17 out of 55) of the students who had problems with technology stated that it was due to the malfunctioning of some of the websites to be used for the completion of assignments. The free trial on LucidPress desktop publishing online site was a major website that students had issues with. A few students (6 out of 55) even identified Canvas as a website that was not working well.

\subsubsection{Time Management}

A small number of students ( 8 out of 55) indicated that the blended learning experience was stressful because of their inability to manage their time at home. Two students even commented that if they were not required to do anything at home, they would have enjoyed the experience more. Some forgot to check Canvas about upcoming assignments and deadlines while others were forced to stay up till late hours at night to complete assignments because of busy lives after school.

Some of the comments were as follows: 
"I did not like learning online because I personally did not learn or remember much since I did not really take notes."

“.... I prefer a classroom environment where I get notes and understand what's going on. I don't know the definition for Tourism."

"... but it [the research activity] was an added unnecessary stress especially the case study because we had to go all over and it literally took me a whole day and to find information everywhere all by ourselves. Normally, you know, the case study is in the textbook.... we had to get our own information... and it was very stressful."

“...it was a bit of stress for some students because not all students are good with being independent and going on the internet and looking for information..."

"... I would come really close to the due date of the assignments due to the internet."

"My internet connection was a major problem....."

"My opinion is that I would rather get notes in the class than go through it online because of a lot of technical difficulties."

"It was very hard to use on mobile devices such as iPhones and tablets as some of the quizzes did not adjust to fit the screen...."

5.2 Responses to Sub-Question 2: What Attitudes Do Students Exhibit Towards the Use of the Constructivist Blended Learning Strategy for the Teaching of Geography?

There were a wide variety of answers given, however they fell into the categories of teaching pedagogy and the use of technology. Three students left that section blank while three out of the fifty-five students claimed that they liked nothing about blended learning.

\subsubsection{Teaching Strategies}

When asked about what they liked best about the strategy, there were forty-three responses given that focussed on various aspects of the teaching method utilized during blended learning. Twelve out of fifty-five students commented that they loved its interactive nature. Eight participants (8 out of 55) loved doing the work in groups. Others, ( 7 out of 55), liked the research process that was involved, while six others (6 out of 55) stated what they liked most was how much fun the process of learning was. Three participants ( 3 out of 55) each enjoyed the fact that they did not have to write notes or that they were able to make their own notes based on research. They all enjoyed the opportunity for creativity that blended learning gave and the way it allowed them to apply what they learnt to real life.

The comments given included:

"It was more interactive and interesting and I enjoyed working in groups."

"I liked that it was more interactive and we were involved and we had to write our own notes and not just write what Miss said to write which made it easier to understand and learn."

"The thing I liked the most was that instead of just studying and regurgitating the notes from my book, I actually understood what I was learning through online activity."

"...It helped me to learn to (be) independent and responsible about my own education."

\subsubsection{Aspects of Technology Used}

The other students identified different aspects of technology as what they loved about the blended learning process. Most of these comments were about how much they loved using the various websites ( 7 out of 55 students) and the idea of using the internet in general and the tourism application created by the teacher (5 out of 55 students). Others liked the use of technology, such as in viewing the videos and the discussions that took place on the Canvas LMS (3 out of 55 students). Two students liked the online assessment with one of them pointing out that the quick feedback of these assessments was especially appreciated. Some of comments about technology were:

"I liked the videos and discussions..."

"I loved the visuals and the use of pictures and videos..."

"I like the game we played on the computer..."

"I LOVED using the internet..." 


\subsection{Responses to Sub-Question 3: What Challenges Did Students Experience With the Blended Learning Strategy?}

The answers included challenges using the different aspects of the technology, challenges adjusting to the teaching method employed (especially using the underlying theory of constructivism) and managing their time. One student stated that they experienced no challenges.

\subsubsection{Challenges With Technology}

About thirty-three percent of students (18 out of 55) identified that they had technical difficulties either with their own computers and/or internet connections at home or the websites they were assigned to including Canvas.

"Through the group projects some sites were giving a lot of trouble. As we would put in information and it would randomly delete."

"As mentioned before a lot of issues came up when we used the technology. For example, some sites were new and slightly hard to adapt to."

\subsubsection{Pedagogical Issues}

\subsubsection{Independent Learning}

The challenges experienced here were due to problems adapting to independent learning. Many students (14 out of 55) had problems with creating their own notes instead of relying on the teacher.

"The definitions (researched) were not all the same and it was very difficult in trying to use and put together all the definitions from the different sources."

"I did not learn a lot. I experienced difficulty in learning as the notes were on Canvas but for me I learn a lot in the classroom when we discuss the notes and explain them before we start writing..... I found it difficult doing that amount of research as different sites sometimes gave different information."

\subsubsection{Group Work}

Despite the fact that some students identified group work as what they liked most about the blended learning experience, some students ( 7 out of 55) identified it as a challenge. Most complained that group members were not reliable and did not do their part in group assignments. Comments from the questionnaire included:

"Some challenges I had were working with my group members, because everything was done at home and not here in school [so] I couldn't really ensure that they would do it [their part]."

"The challenges I experienced in learning geography in this way is that sometimes individuals in the group do not do their part on the project and it messes everything up."

In the focus group interview one student stated:

“....the annoying thing about groups sometimes is that one group member didn't want to do her part because she had other work to do so I think I do better individual work because I don't have to rely on anyone once I have my work done...."

\subsubsection{Assignment Volume and Deadlines}

About one quarter (12 out of 55) of the students identified the volume of weekly assignments that needed to be completed by the respective due dates at their main challenge. Some complained that there were too many assignments. Others complained that the assignment due dates were too close. Most of these students (6 out of 12) said that their main challenge was that they often forgot to check when assignments online were due and missed them:

“...I feel like in learning this way we also got a lot more assignments and homework than usual and I was staying up late many nights to get it done before the due dates."

"...sometimes I couldn't find time to complete at home assignments."

"I found the deadlines for each assignment were too close together and henceforth I had to rush everything done..."

"I always forgot to check online to see if my group members needed me to do anything...."

"I found it difficult to get online assignments done because at times I forgot to log in at home or leave it till the last minute." 


\section{Developing}

In this third stage of the Action Research design, work will be done to ensure that the results of this study be put to use in the researcher's classroom. An action research project is only useful to a teacher or his students if there are changes that take place due to the findings of the research (Mertler, 2014). These findings will be used to inform the next cycle of the action research process.

\section{Action Plan}

Based on the findings it is evident that teaching strategies need to be adjusted. It is important to consider a more eclectic style of teaching which includes some directed learning where necessary but with many opportunities for students to engage in independent learning. It should focus on students' ability to think critically and investigate problems.

\section{Reflecting}

Professional reflection is an essential component of action planning. Indeed, the intent of an action research project or study is that there be action taken because of the findings. It is in this reflection stage the teacher/researcher makes plans that respond to the research he or she conducted. It is only through reflection that a teacher can make effective changes in their practice in the classroom. Mertler (2014) describes two main ways that teachers should engage in reflective practice as a part of their action planning. The first way is for teachers to "reflect on intended as well as unintended outcomes of the study for the purpose of planning future professional development" (Mertler, 2014, p. 220). He also suggested that teachers "should also reflect on the action research study itself, focusing primarily on the methodology employed" (p.220)

\section{Conclusion}

The findings of this study show that students are of the perception that a constructivist blended learning approach created a better classroom atmosphere since it made classes more interesting and enjoyable, allowed for increased interactivity, allowed them to become active learners and gave them a better understanding of the topic. It was also perceived as an innovative and effective use of technology since it was in keeping with the advances in technology worldwide and it allowed technology to be used for education. However, they also thought that the constructivist blended learning approach was stressful and difficult. This is because the teacher did not transmit enough content through notes to them, there was too much emphasis on independent learning, technology was not very reliable and some did not like using technology or were not tech savvy.

Students liked many different aspects of the strategy including the interactivity that was encouraged due to the use of the principles of constructivism. They also loved the opportunity to express their creativity and some liked having the chance to engage in independent learning. Students also enjoyed having the opportunity to work with classmates in group assignments and presentations and they enjoyed the different features of technology employed such as internet usage, videos, and discussion boards on the LMS, online assessments and interactive games.

However, students faced some challenges during the blended learning process. These included unreliable internet access at home and the inability to properly navigate websites online. Students also had challenges with independent learning. They found it difficult to adapt to this type of learning after being exposed to a directed approach for most of their academic careers. Some students found group work to be a challenge since some group members did not contribute to work in a timely manner. Others found it difficult to manage the volume of work to be done and the deadlines that were set for the activities.

Considering the Caribbean's legacy of plantation pedagogy, longitudinal studies also need to be done to show how blended learning can be applied to promote higher level cognitive skills such as analytical and critical thinking and the development of self-regulated learners. If not, the Caribbean will continue to produce students who lack creativity, problem solving skills and who see education just about earning good grades or passing and failing exams. This would impede the development of future citizens who are autonomous, knowledgeable and critical thinkers that delight in working to make their country a better place.

\section{References}

Abidoye, J. A. (2015). The effect of blended learning instructional approach on secondary school students' academic achievement in geography in Akure, Ondo State, Nigeria. Research Journal of Educational Studies and Review, 1(5), 106-110.

Al-Huneidi, A. M., \& Schreurs, J. (2012). Constructivism based blended learning in higher education. International Journal of Emerging Technologies in Learning, 7(1), 4-9. 
https://doi.org/10.3991/ijet.v7i1.1792

Al-Nofli, M. A. (2010). Students' perceptions about geography: A study of basic education school students in Oman. European Journal of Social Sciences, 16(1), 11-20. Retrieved from http://www.scopus.com/inward/record.url?eid=2-s2.0-77958610291\&partnerID=40\&md5=6d4233b2ae784 $83 \mathrm{c} 6 \mathrm{e} 1 \mathrm{edb} 347 \mathrm{~d} 4 \mathrm{c} 32 \mathrm{a} 5$

Bailey, J., Ellis, S., Schneider, C., \& Ark, T. V. (2013). Blended learning implementation guide. Retrieved from http://net.educause.edu/ir/library/pdf/CSD6190.pdf

Birbal, R., \& Hewitt-bradshaw, I. (2016). First-year university students' perspectives and experiences of the flipped classroom strategy in a technology course. Caribbean Curriculum, 24, 27-51.

Bryan, A., \& Volchenkova, K. (2016). Blended learning: definitions, models, implications for higher learning. South Ural State University. https://doi.org/10.14529/ped160204

Caribbean Examinations Council. (2015). Geography Syllabus.

Caribbean Examinations Council. (2017). CSEC geography: syllabus, specimen papers, mark scheme, subject reports.

Collymore, J. C. (2013). Enhancing student performance: linking the geography curriculum, instruction and assessment in the English-speaking Caribbean. The Pennsylvania State University. Retrieved from https://search.proquest.com/openview/06afb8324c4332ecedbcc6e5a5ee6092/1.pdf?pq-origsite=gscholar\&c $\mathrm{bl}=18750 \&$ diss $=\mathrm{y}$

Creswell, J. W. (2012). Educational research: Planning, conducting, and evaluating quantitative and qualitative research (Vol. 4). Pearson. https://doi.org/10.1017/CBO9781107415324.004

Dikmenli, Y., \& Unaldi, U. (2013). Effect of the blended learning environment and the application of virtual class upon the achievement and the attitude against the geography course. Mevlana International Journal of Education, 3(2), 43-56.

Gharacheh, A. M. A., Esmaeili, Z., Farajollahi, M., \& Jamalzadeh, M. (2016). Presentation of blended learning conceptual pattern based on individual and social constructivism theory. International Journal of Humanities and Cultural Studies, (1), 1126-1149. Retrieved from http://www.ijhcs.com/index.php/ijhcs/index

Hesse, L. (2017). The effects of blended learning on K-12th grade students. Retrieved from https://scholarworks.uni.edu/grp\%0Ahttps://scholarworks.uni.edu/grp/116

Hrastinski, S. (2019). What do we mean by blended learning. Tech Trends, 63, 564-569. https://doi.org/10.1007/s11528-019-00375-5

Korkmaz, O., \& Karakus, U. (2009). The impact of blended learning model on student attitudes towards geography course and their critical thinking. The Turkish Online Journal of Educational Technology, 8(4), 51-63.

Kubiatko, M., Janko, T., \& Mrazkova, K. (2012). Czech student attitudes towards Geography. Journal of Geography, 111(2), 67-75. https://doi.org/10.1080/00221341.2011.594904

Lalima, \& Dangwal, K. L. (2017). Blended learning: an innovative approach. Universal Journal of Educational Research, 5(1), 129-136. https://doi.org/10.13189/ujer.2017.050116

Li, X. (2017). A blended learning model of English teaching methodology course guided by constructivism. International Journal of Continuing Engineering Education and Life-Long Learning, 27(1/2), 101. https://doi.org/10.1504/IJCEELL.2017.081000

Martinsen, B., Jackson, C., \& Whitehouse, H. (2015). Student perceptions of using blended learning in secondary science. The European Conference on Technology in the Classroom (pp. 97-110).

Mertler, C. A. (2014). Action research: Improving schools and empowering educators (4th ed.). Thousand Oaks, CA: SAGE.

Mills, G. E. (2000). Action research: a guide for the teacher researcher: Prentice-Hall, Inc. One Lake Street, Upper Saddle River, New Jersey 07458.

Olusegun, S. (2015). Constructivism learning theory: a paradigm for teaching and learning. IOSR Journal of Research \& Method in Education Ver. I, 5(6), 2320-7388. https://doi.org/10.9790/7388-05616670 
Ozdemir, U. (2012). High school students' attitudes towards geography courses. World Applied Sciences Journal, $17(3), 340-346$.

Roofe-Bowen, C. G., Onyefulu, C., Salmon-Ferguson, K., Thomas, A., \& Barrett, S. (2011). Attitudes to online learning : the graduate students' perspective. Journal of Arts Science and Technology, 4, 37-54.

Sagor, R. (2004). The action research guidebook: A four-step process for educators and school teams. Thousand Oaks, CA: Sage.

Sax, C., \& Fisher, D. (2001). Using qualitative action research to effect change: Implications forprofessional education. Teacher Education Quarterly, 28(2), 71-80.

Schunk, D. H. (2012). Learning theories: an educational perspective (Chapter 4 and 6, pp. 117-276). Upper Saddle River, NJ: Pearson.

Thaiposri, P., \& Wannapiroon, P. (2015). Enhancing students' critical thinking skills through teaching and learning by inquiry-based learning activities using social network and cloud computing. Procedia - Social and Behavioral Sciences, 174, 2137-2144. https://doi.org/10.1016/j.sbspro.2015.02.013

Vaughan, N. (2015). Designing for an inquiry based approach to blended and online learning. Revista Eletrônica de Educação, 9(3), 30-47.

Viz, D., \& Kaur, N. (2017). Effect of blended learning approach on achievement in geography at secondary school stage. Scholarly Research Journal for Humanity Science \& English Language, 4(2003), 5478-5485.

White, B., Barnes, A., \& Lawson, M. (2013). Using blended learning for the teaching of high school mathematics. 12th International Conference of The Mathematics Education into the 21st Century Project 2014. https://doi.org/10.13140/2.1.2721.3769

Yapici, I., \& Akbayin, H. (2012). High school students' views on blended learning. Turkish Online Journal of Distance Learning, 13(4), 125-139.

\section{Copyrights}

Copyright for this article is retained by the author(s), with first publication rights granted to the journal.

This is an open-access article distributed under the terms and conditions of the Creative Commons Attribution license (http://creativecommons.org/licenses/by/4.0/). 